\title{
Synthesis and Optical Characterization of Polycyanurates with Pendent Second-Order Nonlinear Optical Chromophores
}

\author{
Dong Cheon ShIN, Youngkyu CHANG, Jin Seok KIm, Icksam NoH, \\ Chulhee KIM, ${ }^{\dagger}$ and Kigook SoNG* \\ Department of Polymer Science and Engineering, \\ Inha University, Inchon 402-751, Korea \\ * Department of Chemical Engineering, \\ Kyunghee University, Yongin, Korea \\ (Received March 12, 1999)
}

\begin{abstract}
A new type of thermally stable second-order nonlinear optical (NLO) polycyanurate was synthesized by coupling Disperse Red 1 to the aryl hydroxyl-containing linear polycyanurate, which was prepared by the interfacial polymerization of 2-(4-(2-tetrahydropyranyloxy)phenyl)-4,6-dichloro-1,3,5-s-triazine with bisphenol A and by subsequent deprotection of tetrahydropyranyl groups. The new NLO polycyanurate exhibited a glass transition at $167^{\circ} \mathrm{C}$ and an initial thermal decomposition at about $300^{\circ} \mathrm{C}$. The electro-optic coefficients of NLO polycyanurate poled at $1 \mathrm{MV} \mathrm{cm}^{-1} \mathrm{were}^{19} \mathrm{pm} \mathrm{V}^{-1}$ at $633 \mathrm{~nm}, 13 \mathrm{pm} \mathrm{V}^{-1}$ at $830 \mathrm{~nm}$, and $6 \mathrm{pm} \mathrm{V}^{-1}$ at $1.3 \mu \mathrm{m}$. The stability of NLO activity was demonstrated at elevated temperatures.

KEY WORDS Nonlinear Optics / Polycyanurates / Chromophores / Thermal Stability / Electro-Optic

Coefficient/
\end{abstract}

High-temperature polymers with second-order nonlinear optical (NLO) chromophores are of great interest as materials for electro-optic modulator and switching application. ${ }^{1}$ The characteristics of polymeric skeleton such as thermal stability, high glass transition temperature, and good film property provide polymeric NLO materials with temporal stability of dipole alignment, and lead to facile thin-film process for effective fabrication and operation of integrated electro-optic devices. $^{2,3}$ One of the most extensively investigated systems is polyimides due to their high $T_{\mathrm{g}}$ and thermal stability. Several polyimide systems were used in prototype electro-optic devices. ${ }^{4-6}$ The synthesis of polyimide, however, generally includes a reaction between reactive diamine and dianhydride for the preparation of poly(amic acid), which then undergoes high-temperature imidization to produce polyimide. Recently, therefore, an introduction of NLO chromophores to poly(hydroxy imide)s via Mitsunobu reaction has been reported as an efficient route to avoid high temperature imidization process. $^{7}$

In this work, we report new thermally stable secondorder NLO polycyanurate which can be prepared under mild interfacial polymerization condition. Cyanurate resins, three dimensional cyanurate networks, have found industrial applications because of their attractive high temperature characteristics. ${ }^{8,9}$ Linear polycyanurates derived from interfacial polymerization of $2-R-4,6-$ chloro-s-triazine and aromatic diols possess excellent thermal stability, high $T_{\mathrm{g}}$, optical transparency, and high solubility in common organic solvents. ${ }^{10,11}$ Thus, linear polycyanurates can be considered suitable candidates for thermally stable NLO materials.

\section{EXPERIMENTAL}

\section{Materials}

4-Bromophenol, pyridinium $p$-toluene sulfonate, cyanuric chloride, sodium hydride, diethyl azodicarboxylate, triphenylphosphine, magnesium turning, and 3,4-dihydro- $2 H$-pyran were purchased from Aldrich and used as received. Cetyldimethylbenzylammonium chloride and sodium hydroxide were obtained from Tokyo Kasei. Disperse Red 1 (DR 1, Aldrich) was recrystallized with $n$-hexane/methylene chloride. 4,4'-Isopropylidenediphenol (Aldrich) was recrystallized with $\mathrm{H}_{2} \mathrm{O}$ /acetic acid. All the solvents were purified following the standard procedures reported in the literature. ${ }^{12}$

\section{Measurements \\ ${ }^{1} \mathrm{H}(250 \mathrm{MHz})$ and ${ }^{13} \mathrm{C}$ NMR $(56 \mathrm{MHz})$ spectra were obtained from Bruker AC 250 spectrometer. Molecular weights and molecular weight distributions were determined using a GPC equipped with Waters As- sociates 410 RI detector, 510 HPLC pump and $\mu$ - Styragel columns with pore sizes of $10^{2}, 500,10^{3}$, and $10^{4} \AA$. The eluent was tetrahydrofuran (THF) and the molecular weights were calibrated with polystyrene standards. UV-Vis spectra were obtained using a Hewlett-Packard 8452A spectrophotometer. Differential scanning calorimeter (DSC) and thermogravimetry (TG) were performed with PL thermal analyzer. The electro-optic coefficient was measured by the simple reflection method proposed by Teng et al. ${ }^{13}$ The film processing, poling, and electro-optic measurement procedure was reported by literature in detail. ${ }^{14}$ \\ Synthesis of 2-(2-(4-(4'-Nitrophenylazo)-N-ethylphenyl-
amino $)$ ethoxy)-4,6-dichloro-1,3,5-s-triazine $(\mathbf{1})$
THF $(80 \mathrm{~mL})$ solution of DR $1(8.2 \mathrm{~g}, 26 \mathrm{mmol})$ and}

\footnotetext{
† To whom correspondence should be addressed (e-mail: chk@inha.ac.kr).
} 
sodium hydride $(1.2 \mathrm{~g}, 30 \mathrm{mmol})$ was stirred at RT for $4 \mathrm{~h}$. After $\mathrm{H}_{2}$ bubbles ceased, this solution was added to a THF $(80 \mathrm{~mL})$ solution of cyanuric chloride $(7.2 \mathrm{~g}$, $39 \mathrm{mmol}$ ). The solution mixture was stirred for $5 \mathrm{~h}$ at $-10^{\circ} \mathrm{C}$. After evaporation of the solvent, the residue was dissolved in methylene chloride and washed with water. The organic layer was dried over anhydrous magnesium sulfate and the solvent was removed at reduced pressure. The crude product was column chromatographed and recrystallized with $n$-hexane/methylene chloride to yield red powder. (yield: $2.4 \mathrm{~g}, 20 \%$ ), $\mathrm{mp}=169-170^{\circ} \mathrm{C} ; \lambda_{\max }\left(\mathrm{CHCl}_{3}\right) 462 \mathrm{~nm} ; \mathrm{IR}$ (KBr) $2982,1601,1550,1521,1340,1142 \mathrm{~cm}^{-1}$; ${ }^{1} \mathrm{H}$ NMR $\left(\mathrm{CDCl}_{3}\right) \quad \delta \quad 1.29 \quad\left(\mathrm{t}, \quad-\mathrm{N}-\mathrm{CH}_{2} \mathrm{CH}_{3}, 3 \mathrm{H}\right), 3.60 \quad(\mathrm{q}$, $\left.-\mathrm{N}-\mathrm{CH}_{2} \mathrm{CH}_{3}, 2 \mathrm{H}\right), 3.87\left(\mathrm{t},-\mathrm{N}-\mathrm{CH}_{2} \mathrm{CH}_{2}-\mathrm{O}-\mathrm{Ph}-, 2 \mathrm{H}\right)$, $4.70\left(\mathrm{t},-\mathrm{N}-\mathrm{CH}_{2} \mathrm{CH}_{2}-\mathrm{O}-\mathrm{Ph}-, 2 \mathrm{H}\right), 6.84(\mathrm{~d},-\mathrm{N}-\mathrm{Ph}-\mathrm{N}=$ $\mathrm{N}-(\mathrm{o}), 2 \mathrm{H}), 7.84(\mathrm{~d},-P h-\mathrm{N}=\mathrm{N}-P h-(\mathrm{o}), 4 \mathrm{H}), 8.32$ (d, $\left.\mathrm{NO}_{2}-\mathrm{Ph}-(\mathrm{o}), 2 \mathrm{H}\right) ;{ }^{13} \mathrm{C} \mathrm{NMR}\left(\mathrm{CDCl}_{3}\right) \delta 12.3,46.2,48.5$, 66.8, 76.5, 111.5, 122.7, 124.7, 126.3, 144.1, 147.5, 150.7, 156.6, 170.9, 172.7; MS (m/z) 461, 463, 465; Anal. Calcd for $\mathrm{C}_{19} \mathrm{H}_{17} \mathrm{~N}_{7} \mathrm{Cl}_{2} \mathrm{O}_{3}$ : C, 49.32; $\mathrm{H}, 3.68 ; \mathrm{N}, 21.20$. Found: C, 49.31; H, 3.72; N, 20.79.

\section{Synthesis of 1-Bromo-4-(2-tetrahydropyranyloxy)benzene} (2)

A dry methylene chloride $(100 \mathrm{~mL})$ solution of $3,4-$ dihydro-2 $H$-pyran $(12.6 \mathrm{~g}, 150 \mathrm{mmol})$ was added to a methylene chloride $(100 \mathrm{~mL})$ solution of 4-bromophenol (17.3 g, $100 \mathrm{mmol})$ and pyridinium $p$-toluenesulfonate (PPTS) (2.5 g, $10 \mathrm{mmol})$. The solution was stirred for $6 \mathrm{~h}$ at room temperature, then washed with water to remove the remaining PPTS and dried over anhydrous magnesium sulfate. After removal of the solvent, the crude product was recrystallized from $n$-hexane/methylene chloride. (yield: $24.4 \mathrm{~g}, 95 \%$ ), $\mathrm{mp}=48-49^{\circ} \mathrm{C} ; \lambda_{\max }$ $\left(\mathrm{CHCl}_{3}\right) 244 \mathrm{~nm}$; IR (KBr) 2945, 1487, 1236, 1174, 1116, $1070,957 \mathrm{~cm}^{-1} ;{ }^{1} \mathrm{H} \mathrm{NMR}\left(\mathrm{CDCl}_{3}\right) \delta 1.56-2.02(\mathrm{~m}$, $\left.-\mathrm{CHCH}_{2} \mathrm{CH}_{2} \mathrm{CH}_{2} \mathrm{CH}_{2} \mathrm{O}-, 6 \mathrm{H}\right), 3.60$ (m, $-\mathrm{CHCH}_{2}-$ $\left.\mathrm{CH}_{2} \mathrm{CH}_{2} \mathrm{CH}(1) \mathrm{H}(2) \mathrm{O}-, 1 \mathrm{H}\right), 3.80\left(\mathrm{~m},-\mathrm{CHCH}_{2} \mathrm{CH}_{2}-\right.$ $\left.\mathrm{CH}_{2} \mathrm{CH}(1) \mathrm{H}(2) \mathrm{O}-, 1 \mathrm{H}\right), 5.46\left(\mathrm{t}, \mathrm{J}=3.1 \mathrm{~Hz},-\mathrm{CHCH}_{2}^{-}\right.$ $\left.\mathrm{CH}_{2} \mathrm{CH}_{2} \mathrm{CH}_{2} \mathrm{O}-, 1 \mathrm{H}\right) 6.93(\mathrm{~d}, \mathrm{~J}=8.7 \mathrm{~Hz}, \mathrm{Py}-\mathrm{O}-\mathrm{Ph}-(\mathrm{o})$, $2 \mathrm{H}), 7.36(\mathrm{~d}, J=8.7 \mathrm{~Hz},-\mathrm{O}-\mathrm{Ph}-\mathrm{Br}(\mathrm{m}), 2 \mathrm{H}) ;{ }^{13} \mathrm{C}$ NMR $\left(\mathrm{CDCl}_{3}\right) \delta 18.6,25.1,30.2,61.9,96.4,113.7,118.2,132.1$, 156.1; $\mathrm{MS}(\mathrm{m} / \mathrm{z}) 256,258$ (CI); Anal. Calcd for $\mathrm{C}_{11} \mathrm{H}_{13} \mathrm{BrO}_{2}: \mathrm{C}, 51.34 ; \mathrm{H}, 5.06$. Found: C, 51.72; H, 5.17.

\section{Synthesis of 2-(4-(2-Tetrahydropyranyloxy)phenyl)-4,6- dichloro-1,3,5-s-triazine (3)}

A THF $(80 \mathrm{~mL})$ solution of 1-bromo-4-(2-tetrahydropyranyloxy)benzene $(10 \mathrm{~g}, 39 \mathrm{mmol})$ Grignard reagent was added to a THF $(80 \mathrm{~mL})$ solution of cyanuric chloride $(7.2 \mathrm{~g}, 39 \mathrm{mmol})$. The solution was stirred for $5 \mathrm{~h}$ at $-10^{\circ} \mathrm{C}$. After evaporation of the solvent, the residue was dissolved in methylene chloride and washed with water. The organic layer was dried over anhydrous magnesium sulfate and the solvent was removed at reduced pressure. The crude product was recrystallized from $n$-hexane. (yield: $4.5 \mathrm{~g}, 35 \%), \lambda_{\max }\left(\mathrm{CHCl}_{3}\right) 294 \mathrm{~nm}$;; IR (KBr) 2947, 1558, 1497, 1392, 1241, 1175, 1015, $928 \mathrm{~cm}^{-1} ;{ }^{1} \mathrm{H} \quad \mathrm{NMR} \quad\left(\mathrm{CDCl}_{3}\right) \quad \delta \quad 1.55-2.02 \quad(\mathrm{~m}$, $\left.-\mathrm{CHCH}_{2} \mathrm{CH}_{2} \mathrm{CH}_{2} \mathrm{CH}_{2} \mathrm{O}-, 6 \mathrm{H}\right), 3.60\left(\mathrm{~m},-\mathrm{CHCH}_{2} \mathrm{CH}_{2}-\right.$ $\left.\mathrm{CH}_{2} \mathrm{CH}(1) \mathrm{H}(2) \mathrm{O}-, 1 \mathrm{H}\right), 3.85\left(\mathrm{~m},-\mathrm{CHCH}_{2} \mathrm{CH}_{2} \mathrm{CH}_{2}-\right.$ $\mathrm{CH}(1) H(2) \mathrm{O}-, 1 \mathrm{H}), 5.51\left(\mathrm{t}, J=3.1 \mathrm{~Hz},-\mathrm{CHCH}_{2} \mathrm{CH}_{2}\right.$ -
$\left.\mathrm{CH}_{2} \mathrm{CH}_{2} \mathrm{O}-, 1 \mathrm{H}\right), 7.07(\mathrm{~d}, \mathrm{~J}=8.7 \mathrm{~Hz}, \mathrm{Py}-\mathrm{O}-\mathrm{Ph}-(\mathrm{o}), 2 \mathrm{H})$, $8.35(\mathrm{~d}, J=8.7 \mathrm{~Hz},-\mathrm{O}-P h$-Triazine $(\mathrm{m}), 2 \mathrm{H}) ;{ }^{13} \mathrm{C}$ NMR $\left(\mathrm{CDCl}_{3}\right) \delta 18.3,24.9,29.9,61.9,96.0,116.5,125.4,132.0$, 162.6, 171.5, 174.0.; MS $(m / z) 325,327,329$.

\section{Synthesis of Polymer 4}

A solution of $3(9.8 \mathrm{~g}, 30 \mathrm{mmol})$ in chloroform $(80 \mathrm{~mL})$ was kept at room temperature. To this solution, a solution of 4,4'-isopropylidenediphenoxide $(7 \mathrm{~g}, 30 \mathrm{mmol})$ in water $(100 \mathrm{~mL})$ with cetyldimethylbenzylammonium chloride $(1.2 \mathrm{~g}, 3 \mathrm{mmol})$ was rapidly added with vigorous stirring. The reaction mixture was stirred for $48 \mathrm{~h}$ at room temperature. After removing the aqueous phase, the polymer solution was precipitated into methanol, and the precipitate was collected by filtration. Further purification was performed by repeated precipitation from THF into water and methanol to produce a powdery polymer 4 . (yield: $12 \mathrm{~g}, 68 \%), \lambda_{\max }($ film $)=$ $298 \mathrm{~nm}$; IR (KBr) 2940, 1561, 1499, 1352, 1296, 1167, $1015,957 \mathrm{~cm}^{-1} ;{ }^{1} \mathrm{H}$ NMR $\left(\mathrm{CDCl}_{3}\right) \delta 1.47-2.05(\mathrm{~m}$, $-\mathrm{CHCH}_{2} \mathrm{CH}_{2} \mathrm{CH}_{2} \mathrm{CH}_{2} \mathrm{O}-$ and $\left.-\mathrm{C}\left(\mathrm{CH}_{3}\right)_{2}-, 12 \mathrm{H}\right), 3.58$ (m, $\left.-\mathrm{CHCH}_{2} \mathrm{CH}_{2} \mathrm{CH}_{2} \mathrm{CH}(1) \mathrm{H}(2) \mathrm{O}-, 1 \mathrm{H}\right), 3.79$ (m, $\left.-\mathrm{CHCH}_{2} \mathrm{CH}_{2} \mathrm{CH}_{2} \mathrm{CH}(1) \mathrm{H}(2) \mathrm{O}-, 1 \mathrm{H}\right), 5.45$ (br, $-\mathrm{CH}-$ $\left.\mathrm{CH}_{2} \mathrm{CH}_{2} \mathrm{CH}_{2} \mathrm{CH}_{2} \mathrm{O}-, 1 \mathrm{H}\right), 7.01$ (d, Py-O-Ph- (o), 2H), $7.17\left(\mathrm{~d},-P h-\mathrm{C}\left(\mathrm{CH}_{3}\right)_{2}-P h-(\mathrm{o}), 4 \mathrm{H}\right), 7.30$ (d, $-P h-$ $\left.\mathrm{C}\left(\mathrm{CH}_{3}\right)_{2}-\mathrm{Ph}-(\mathrm{m}), 4 \mathrm{H}\right), 8.19(\mathrm{~d},-\mathrm{O}-\mathrm{Ph}$-Triazine $(\mathrm{m})$, $2 \mathrm{H}) ;{ }^{13} \mathrm{C} \mathrm{NMR}\left(\mathrm{CDCl}_{3}\right) \delta 18.4,25.1,30.0,31.1,42.5$, $61.9,95.9,116.1,121.0,127.6,127.8,131.0,147.9,149.8$, 161.3, 172.8, 175.1; Anal. Calcd for $\left(\mathrm{C}_{29} \mathrm{H}_{27} \mathrm{~N}_{3} \mathrm{O}_{4}\right)_{n}: \mathrm{C}$, 72.27; H, 5.61; N, 8.72. Found: C, 72.03; H, 5.75; N, 8.86. $M_{n}=66000, M_{w} / M_{n}=2.4$; Deprotection occurred at $216^{\circ} \mathrm{C}$.

\section{Synthesis of Polymer 5}

A solution of polymer 4 (3.5 g, $7.3 \mathrm{mmol}$ repeat unit) and PPTS $(0.18 \mathrm{~g}, 0.7 \mathrm{mmol})$ in ethanol/THF $(1: 1, \mathrm{v} / \mathrm{v})$ was stirred for $12 \mathrm{~h}$ at $45^{\circ} \mathrm{C}$. After removing the solvent, the polymer was dissolved in THF and was precipitated into water. The precipitate was collected by filtration. Further purification was performed by repeated precipitation from THF into methanol to produce a powdery polymer 5. $\lambda_{\max }($ film $)=302 \mathrm{~nm}$; IR (KBr) 3325 , $1699,1558,1457,1205,1063,928 \mathrm{~cm}^{-1} ;{ }^{1} \mathrm{H}$ NMR $\left(\mathrm{DMSO}-d_{6}\right) \delta 1.65\left(\mathrm{~s},-\mathrm{C}\left(\mathrm{CH}_{3}\right)_{2}-, 6 \mathrm{H}\right), 6.79(\mathrm{~d}, \mathrm{OH}-$ $P h-(\mathrm{o}), 2 \mathrm{H}), 7.17$ (d, $\left.-P h-\mathrm{C}\left(\mathrm{CH}_{3}\right)_{2}-P h-(\mathrm{o}), 4 \mathrm{H}\right), 7.26$ $\left(\mathrm{d},-P h-\mathrm{C}\left(\mathrm{CH}_{3}\right)_{2}-P h-(\mathrm{m}), 4 \mathrm{H}\right), 7.99$ (d, -O-Ph-Triazine $(\mathrm{m}), 2 \mathrm{H}), 10.33(\mathrm{~s},-\mathrm{Ph}-\mathrm{OH}, 1 \mathrm{H}) ;{ }^{13} \mathrm{C}$ NMR $\left(\mathrm{DMSO}-d_{6}\right) \delta 30.5,42.1,115.6,121.1,124.9,127.5$, 130.8, 1427.6, 149.5, 162.4, 172.2, 174.5; Anal. Calcd for $\left(\mathrm{C}_{24} \mathrm{H}_{19} \mathrm{~N}_{3} \mathrm{O}_{3}\right)_{n}$ : C, 72.46; H, 4.78; N, 10.57. Found: C, 72.68; H, 4.97; N, 10.30. $M_{n}=44000, M_{w} / M_{n}=$ $1.7 ; T_{\mathrm{g}}=220^{\circ} \mathrm{C}$.

\section{Synthesis of Polymer 6}

A solution of polymer $5(1 \mathrm{~g}, 2.5 \mathrm{mmol}$ repeat unit), DR 1 (2.4 g, $7.5 \mathrm{mmol})$, and triphenylphosphine $(2 \mathrm{~g}$, $7.5 \mathrm{mmol})$ in THF $(80 \mathrm{~mL})$ was added to a solution of diethyl azodicarboxylate (DEAD) $(3.3 \mathrm{~g}, 7.5 \mathrm{mmol})$ in THF $(10 \mathrm{~mL})$ for $24 \mathrm{~h}$ at room temperature. After completion of the reaction, the polymer solution was poured into methanol. The precipitate was collected by filtration. Further purification was performed by repeated precipitation from THF into methanol to produce a red 
D. C. SHIN et al.

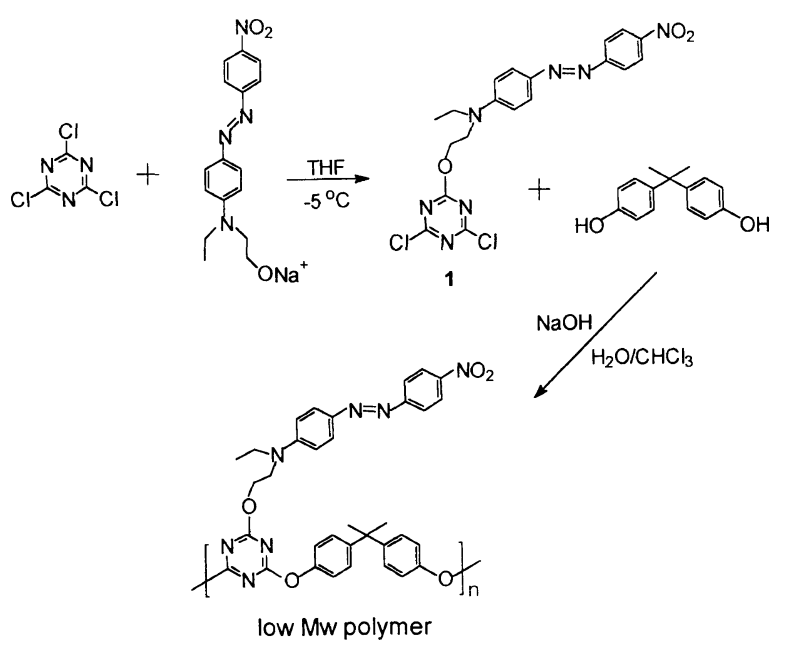

Scheme 1.

powdery polymer 6. $\lambda_{\max }($ film $)=300$ and $486 \mathrm{~nm}$; IR (KBr) 2975, 1601, 1558, 1419, 1374, 1337, 1251, 1133, $1017 \mathrm{~cm}^{-1} ;{ }^{1} \mathrm{H}$ NMR (DMSO- $\left.d_{6}\right) \delta 1.15$ (br, $-\mathrm{N}-$ $\left.\mathrm{CH}_{2} \mathrm{CH}_{3}, 3 \mathrm{H}\right), 1.63$ (s, $\left.-\mathrm{C}\left(\mathrm{CH}_{3}\right)_{2}-, 6 \mathrm{H}\right), 3.53$ (br, $\left.-\mathrm{N}-\mathrm{CH}_{2} \mathrm{CH}_{3}, 2 \mathrm{H}\right), 3.79$ (br, $\left.-\mathrm{N}-\mathrm{CH}_{2} \mathrm{CH}_{2}-\mathrm{O}-\mathrm{Ph}-, 2 \mathrm{H}\right)$, 4.16 (br, $\left.-\mathrm{N}-\mathrm{CH}_{2} \mathrm{CH}_{2}-\mathrm{O}-\mathrm{Ph}-, 2 \mathrm{H}\right), 6.75$ (br, $-\mathrm{N}-\mathrm{Ph}-$ $\mathrm{N}=\mathrm{N}-(\mathrm{o}), 2 \mathrm{H}), 6.81\left(\mathrm{br},-\mathrm{CH}_{2}-\mathrm{O}-\mathrm{Ph}-(\mathrm{o}), 2 \mathrm{H}\right), 7.12$ (br, $\left.-P h-\mathrm{C}\left(\mathrm{CH}_{3}\right)_{2}-P h-(\mathrm{o}), 4 \mathrm{H}\right), 7.23\left(\mathrm{br},-P h-\mathrm{C}\left(\mathrm{CH}_{3}\right)_{2}\right.$ $P h-(\mathrm{m}), 4 \mathrm{H}), 7.84$ (br, $-P h-\mathrm{N}=\mathrm{N}-P h-(\mathrm{o}), 4 \mathrm{H})$, $8.03-8.35\left(\mathrm{br},-\mathrm{O}-\mathrm{Ph}\right.$-Triazine $(\mathrm{m})$ and $\mathrm{NO}_{2}-\mathrm{Ph}-(\mathrm{o})$, $4 \mathrm{H}) ;{ }^{13} \mathrm{C}$ NMR (DMSO- $\left.d_{6}\right) \delta 12.2,30.9,42.5,46.1,49.5$, $111.4,114.2,120.9,122.5,124.6,126.2,127.7,131.3$, 147.8, 149.7, 172.6; Anal. Calcd for $\left(\mathrm{C}_{40} \mathrm{H}_{35} \mathrm{~N}_{7} \mathrm{O}_{5}\right)_{n}$ : C, 69.19; H, 5.05; N, 14.13. Found: C, 68.74; H, 5.08; N, 13.82. $M_{n}=37000, M_{w}{ }^{\prime} M_{n}=2.4 ; T_{\mathrm{g}}=167^{\circ} \mathrm{C}$.

\section{RESULTS AND DISCUSSION}

Initial attempts to prepare NLO polycyanurates began with the synthesis of triazine monomer 1 which contains DR 1 as a chromophore. We tried interfacial polymerization of monomer 1 with aromatic diols such as $4,4^{\prime}$-isopropylidenediphenol or 4,4'-hexafluoroisopropylidenediphenol (Scheme 1).

However, the molecular weights of the polymer product were in the range of several thousand, which is not high enough to obtain a high quality spin-coated film with several microns thickness. The relatively low molecular weight of polycyanurate polymers obtained might be due to steric effects in the monomer molecule. In order to increase the molecular weight of the polycyanurates with DR 1, we prepared the high molecular weight precursor polycyanurates with hydroxyl functionality, which were then allowed to react with the chromophore to yield NLO polycyanurates with increased molecular weights (Scheme 2). The synthesis of precursor polycyanurates begins with the preparation of triazine monomer 3 , which was obtained by the replacement of one chlorine atom of cyanuric chloride by the 4-tetrahydropyranyloxy phenyl group.

The selective reactivity of chlorine atoms of cyanuric chloride provides facile synthesis of the mono-substituted triazine monomer $3 .^{15}$ The interfacial polymerization of monomer 3 with $4,4^{\prime}$-isopropylidenediphenol produced
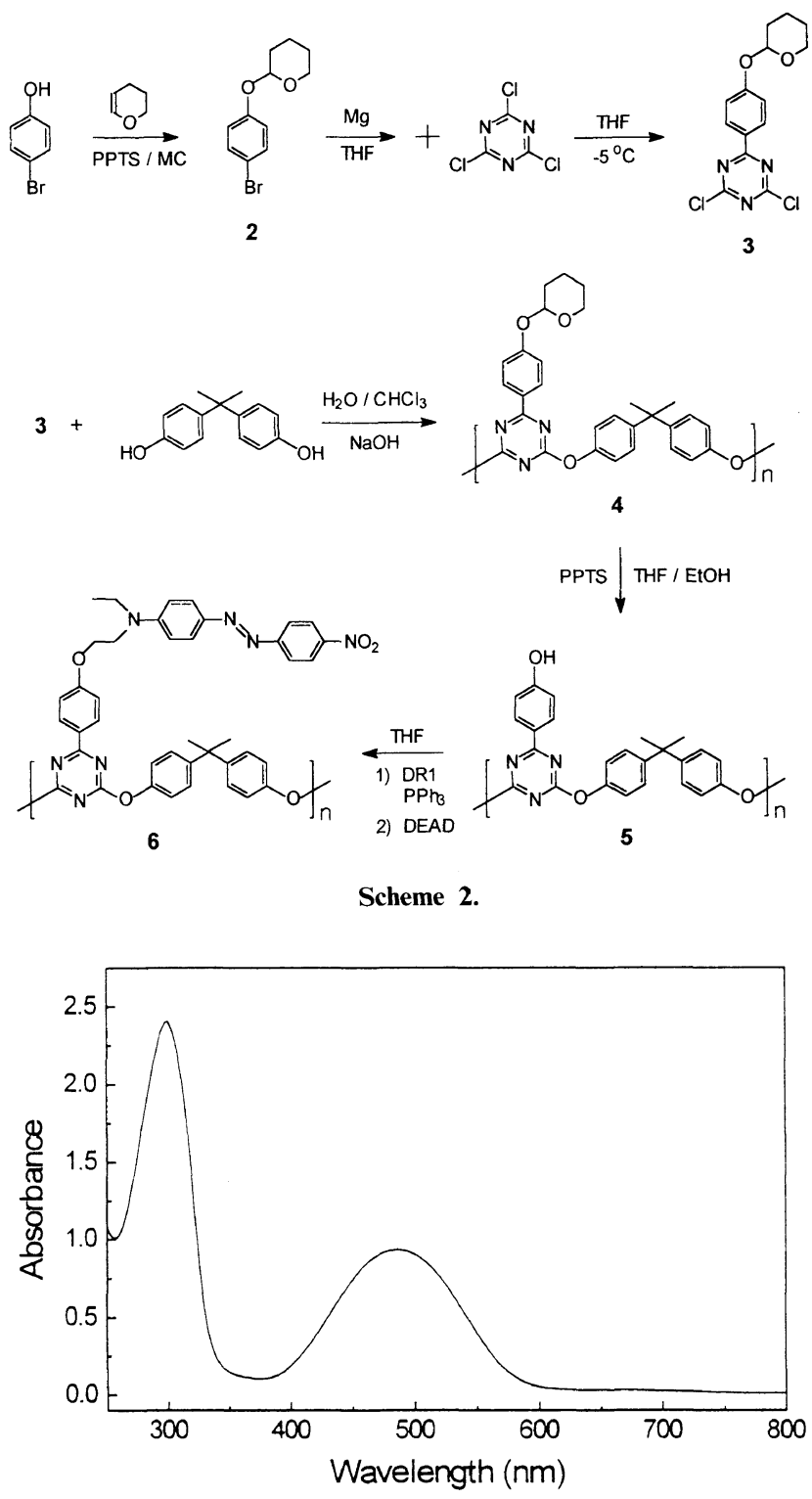

Figure 1. UV-Vis spectrum of polymer 6.

polymer 4. ${ }^{16}$ The polymer was soluble in chloroform, THF, $N, N$-dimethyl formamide (DMF), and DMSO. As summarized in Table I, the $M_{n}$ value was about 66000 with $M_{w} / M_{n}=2.4$. Deprotection of tetrahydropyranyloxy protecting group was attempted in ethanol/THF $(1: 1, \mathrm{v} / \mathrm{v})$ in the presence of PPTS to yield polycyanurate which has hydroxyl functionality to accommodate the NLO chromophore. ${ }^{17}$ Total deprotection was confirmed by the disappearance of resonance peaks due to the tetrahydropyranyloxy moiety in the ${ }^{1} \mathrm{H}$ NMR spectrum. However, a slight acidic deprotection condition caused a decrease in $M_{n}$ of the polycyanurate 5 to 44000 , which could possibly be attributed to the cleavage of $\mathrm{C}-\mathrm{O}-\mathrm{C}$ linkage between aryloxy units and the triazine ring which has high electron affinity. ${ }^{18}$ Polymer 5 was soluble in chloroform, THF, and DMF and exhibited a glass transition at $220^{\circ} \mathrm{C}$. In addition, it had high thermal stability in the solid state. Polymer 5 was allowed to undergo a Mitsunobu reaction with DR 1 to yield NLO polycyanurate $\mathbf{6}$, which was soluble in THF, cyclohexanone, chloroform, and DMF. The ${ }^{1} \mathrm{H}$ NMR analysis of polymer 6 indicates that the hydroxyl 
Table I. Molecular weights and thermal properties of polycyanurates

\begin{tabular}{cccc}
\hline Polymer & $M_{n}{ }^{\mathrm{a}}$ & $M_{w} / M_{n}$ & $T_{\mathrm{g}}$ \\
\hline $\mathbf{4}$ & 66000 & 2.4 & - \\
$\mathbf{5}$ & 44000 & 1.7 & 220 \\
$\mathbf{6}$ & 37000 & 2.4 & 167 \\
\hline
\end{tabular}

${ }^{\text {a }}$ GPC values versus polystyrene standards.

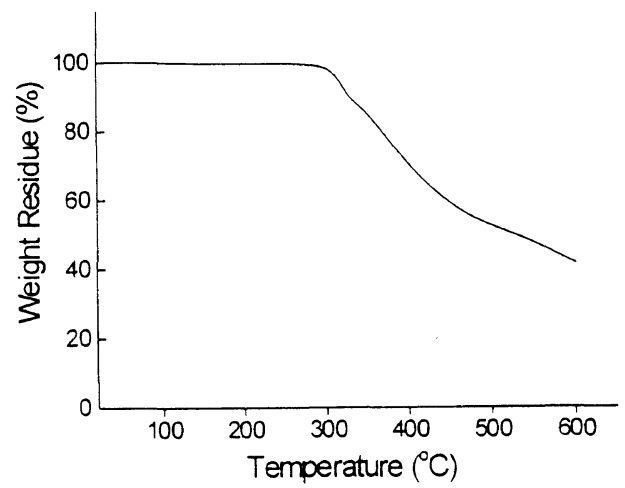

Figure 2. TGA curve of polymer 6 .

groups of polymer 5 were modified by $92 \%$. In polymer 6, the absorption maximum was shown at $482 \mathrm{~nm}$ corresponding to the characteristic absorption of DR 1 chromophore (Figure 1).

The $M_{n}$ of polymer 6 was 37000 with $M_{w} / M_{n}=2.4$. The glass transition was observed at $167^{\circ} \mathrm{C}$ by DSC analysis. The thermal stability of polymer 6 was estimated by TGA, as shown in Figure 2 .

The initial decomposition temperature of polymer 6 was about $300^{\circ} \mathrm{C}$, which indicates that polycyanurates could be a promising NLO material with excellent thermal stability. Since polycyanurate 6 was soluble in organic solvents such as THF, cyclohexanone, 1,1,2,2tetrachloroethane, and DMSO, it could be spin-cast onto an indium tinoxide (ITO) coated glass to give an optically transparent polymer film. For the electro-optic characterization, gold was evaporated as a top electrode on the thin film of polycyanurate 6 cast onto ITO glass, which served as a bottom electrode. A contact poling was attempted to induce dipole alignment of the NLO chromophores by applying electric field to a sandwich type sample. The polymer sample was heated to $160^{\circ} \mathrm{C}$, at which an electric field of $1 \mathrm{MV} \mathrm{cm}^{-1}$ was applied for $10 \mathrm{~min}$, then the temperature was slowly lowered to $60^{\circ} \mathrm{C}$ while maintaining the electric field. ${ }^{19}$ The electro-optic coefficient of the NLO polycyanurate was measured by the simple reflection method proposed by Teng et al. ${ }^{13}$ At a poling field of $1 \mathrm{MV} \mathrm{cm}^{-1}$, the electro-optic coefficients, $r_{33}$, of the NLO polycyanurate 6 was $19 \mathrm{pm} \mathrm{V}^{-1}$ at a wavelength of $633 \mathrm{~nm}, 13 \mathrm{pm} \mathrm{V}^{-1}$ at $830 \mathrm{~nm}$, and $6 \mathrm{pm} \mathrm{V}^{-1}$ at $1.3 \mu \mathrm{m}$ respectively. The temporal stability of $r_{33}$ was measured at $70^{\circ} \mathrm{C}$ as shown in Figure 3. The $r_{33}$ value of polycyanurate 6 after $5 \mathrm{~h}$ at $70^{\circ} \mathrm{C}$ remained at $80 \%$ of the initial $r_{33}$ values.

In summary, a new class of thermally stable NLO polymers, a polycyanurate with chromophore was synthesized by coupling DR 1 to the hydroxyl-containing polycyanurate. This approach can provide a facile synthetic route to NLO polycyanurates with a variety of

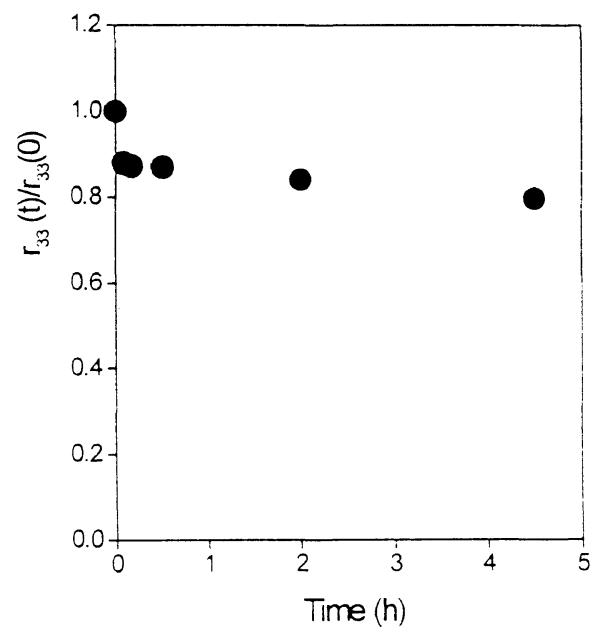

Figure 3. Temporal stability of electro-optic coefficient of polymer 6 at $70^{\circ} \mathrm{C}$.

NLO chromophores. NLO polycyanurate exhibited a glass transition at $167^{\circ} \mathrm{C}$ and an initial decomposition at about $300^{\circ} \mathrm{C}$. The electro-optic coefficients of NLO polycyanurate poled at $1 \mathrm{MV} \mathrm{cm}^{-1}$ were $19 \mathrm{pm} \mathrm{V}^{-1}$ at $633 \mathrm{~nm}, 13 \mathrm{pm} \mathrm{V}^{-1}$ at $830 \mathrm{~nm}$, and $6 \mathrm{pm} \mathrm{V}^{-1}$ at $1.3 \mu \mathrm{m}$, with thermal stability of NLO activity.

Acknowledgment. CK thanks the Inha Research Fund ('98) and KS acknowledges the Ministry of Information and Communication of Korea for support of this work.

\section{REFERENCES AND NOTES}

1. (a) P. Prasad and D. Williams, Ed. "Nonlinear Optical Effects in Molecules and Polymers," John Wiley and Sons, New York, N.Y., 1991. (b) D. M. Burland, R. D. Miller, and C. A. Walsh, Chem. Rev., 94, 31 (1994).

2. (a) J. W. Wu, J. F. Villey, S. Ermer, E. S. Binkley, J. T. Kenney, G. F. Lipscomb, and R. Lytel, Appl. Phys. Lett., 58, 225 (1991). (b) R. Dalton, A. W. Harper, R. Ghosn, W. H. Steier, M. Ziari, H. Fetterman, Y. Shi, R. V. Mustacich, A. K.-Y. Jen, and K. J. Shea, Chem. Mater., 7, 1060 (1995).

3. A. K.-Y. Jen, K. J. Drost, Y. Cai, V. P. Rao, and L. R. Dalton, J. Chem. Soc., Chem. Commun., 965 (1994).

4. K. Y. Wong and A. K.-Y. Jen, J. Appl. Phys., 75, 3308 (1994).

5. (a) M. Chen, L. Yu, L. R. Dalton, Y. Shi, and W. H. Steier, Macromolecules, 24, 5421 (1991). (b) Z. Peng and L. Yu, Macromolecules, 27, 2638 (1994). (c) D. Yu and L. Yu, Macromolecules, 27, 6718 (1994).

6. (a) T. Verbiest, D. M. Burland, M. C. Jurich, V. Y. Lee, R. D. Miller, and W. Volksen, Science, 268, 1604 (1995). (b) T. Verbiest, D. M. Burland, M. C. Jurich, V. Y. Lee, R. D. Miller, and W. Volksen, Macromolecules, 28, 3005 (1995). (c) R. D. Miller, D. M. Burland, M. C. Jurich, V. Y. Lee, C. R. Moylan, J. I. Thackara, R. J. Twieg, T. Verbiest, and W. Volksen, Macromolecules, 28, 4970 (1995).

7. (a) T.-A. Chen, A. K.-Y. Jen, and Y. Cai, J. Am. Chem. Soc., 117, 7295 (1995). (b) T.-A. Chen, A. K.-Y. Jen, and Y. Cai, Macromolecules, 29, 535 (1996).

8. G. Meyer, J. Bauer, and M. Bauer, Polym. Prepr., Am. Chem. Soc., Div. Polym. Mater. Sci. \& Eng., 71, 797 (1994).

9. W. Mormann, and J. G. Zimmermann, Macromolecules, 29, 1105 (1996).

10. P. P. Shah, Eur Polym. J., 20, 519 (1984).

11. S. Kondo, T. Yamamoto, H. Kunisada, and Y. Yuki, J. Macromol. Sci. Chem., A27, 1513 (1990).

12. W. L. F. Armarego and D. D. Perrin, "Purification of Laboratiry Chemicals," 4th ed, Butterworth-Heinemann, Oxford, 1996. 
13. C. C. Teng and H. T. Man, Appl. Phys. Lett, 56, 1734 (1990)

14. (a) D. H. Choi, S. Song, T. S. Lee, S. Y. Park, and N. Kim, J. Appl. Polym. Sci., 59, 9 (1996). (b) H. R. Allcock, A. A. Dembek, C. Kim, R. L. S. Devine, Y. Shi, W. H. Steier, and C. W. Spangler, Macromolecules, 24, 1000 (1991).

15. C. Kim, Y. Chang, and J. S. Kim, Macromolecules, 29, 6353 (1996).

16. R. B. Naik and P. P. Shah, Eur. Polym. J., 25, 193 (1989).
17. N. Miyashita, A. Yoshikoshi, and P. A. Grieco, J. Org. Chem., 42, 3772 (1977).

18. (a) R. Fink, C. Frenz, M. Thelakkat, and H.-W. Schmidt, Macromolecules, 30, 8177 (1997). (b) R. Fink, Y. Heischkel, M. Thelakkat, H.-W. Schmidt, C. Jonda, and M. Hüppauff, Chem. Mater., 10, 3620 (1998)

19. H. Man and H. Yoon, Adv. Mater., 4, 159 (1992). 